\title{
CAUSAL RELATIONSHIP BETWEEN RENEWABLE ENERGY CONSUMPTION AND UNEMPLOYMENT IN NIGERIA: EVIDENCE FROM TODA AND YAMAMOTO CAUSALITY TECHNIQUE
}

\author{
(D) Kabiru Saidu Musa ${ }^{1+}$ \\ (iD) Rabiu Maijama'a ${ }^{2}$
}

\author{
${ }^{\prime}$ Department of Economics, Faculty of Social and Management Sciences, \\ Bauchi State University Gadau, Tuli Campus, Bauchi-Nigeria. \\ Email:kabirusaidumusa@gmail.comTel:+2348030915903 \\ ${ }^{2}$ NNPC Retail Sales Representative, Nigerian National Petroleum \\ Corporation, NNPC Towers, Central Business District, Garki, Abuja- \\ Nigeria. \\ Email:Rabiumaijamaa19@gmail.com Tel:+2348033896237
}

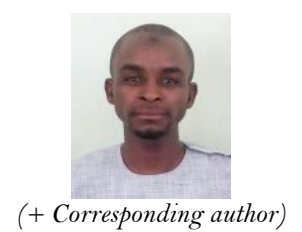

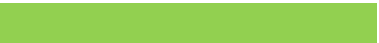

Article History

Received: 6 July 2020

Revised: 12 August 2020

Accepted: 28 August 2020

Published: 10 September 2020

\section{Keywords}

Renewable Energy

Unemployment

Johansen

Juselius Cointegration test

Toda and yamamoto technique

Variance decompositions

Impulse response functions.

JEL Classification: Q20; Q42; J64; C32; O55.

\begin{abstract}
The paper examines the causal association among renewable energy consumption and unemployment in Nigeria for the sample of 1991-2015 periods via the technique of Toda and Yamamoto causality. The outcome of the long-run causality specifies that bidirectional causality exist between renewable energy consumption and unemployment; foreign direct investment and renewable energy consumption; investments and renewable energy consumption; credit to private sector and renewable energy consumption; foreign direct investments and investments; credit to private sector and investments with unidirectional causality among investments and unemployment; credit to private sector and unemployment. This suggests that higher consumption of energy from renewable sources will go a long way in providing the long-lasting solution to the problems of unemployment in the country. It is therefore recommended that Nigerian government should put more efforts on increasing production and consumption of energy from renewable source as it has the tendency of decreasing the rate of unemployment in the long-run and barriers in the form of higher cost of acquisition and taxes on the production and consumption of energy from the renewable sources should be completely eliminated in order to increase the rate of investments in renewable energy technologies and subsequently create employments.
\end{abstract}

Contribution/ Originality: This study contributed to the existing literatures on the relationship influence renewable energy consumption and unemployment in case of Nigeria by employing long-run causality test of T-Y approach and the novelty in this research is in the area of methodology, inclusion of foreign direct investments and the sample size expansion.

\section{INTRODUCTION}

After the occurrence of world crude oil price shocks of 70s, the consumption of energy and the quality of the environment became the key areas of apprehension to the world countries. Changes from nonrenewable to renewable energy consumption policies through improving the environment were among the significant areas in the current race for the achievement of sustainable development goals (SDGs) as over $80 \%$ of the level of consumption of energy in the developing world is from fossil fuel resources and crude oil (Larcher \& Tarascon, 
2015). And because of that, developing nations are having environmental issues and the most important of these problems is the $\mathrm{CO}_{2}$ emissions (Najid Ahmad \& Du, 2017; Ahmad, Du, \& Tian, 2018; Ahmad et al., 2017).

Over the current years, the significance of consuming renewable energy has increased to a great level and the benefits of this renewable energy consumption extending from achieving better quality of the environment to advanced economic growth are well recognized in literature and to mention few of such studies include Sebri and Ben-Salha (2014); Apergis and Danuletiu (2014); ; Ibrahiem (2015); Kahia, Aïssa, and Charfeddine (2016); Khobai and Le Roux (2017) among others. Also, renewable energy consumption provides solutions that ranges from realizing the objective of higher economic growth and authoritative to decarbonization of economies in the world (IRENA, 2016). As part of the ongoing realization of sustainable development goal, consumption of renewable energy helps in securing jobs for the unemployed teeming population and the achievement of improved society's welfare. Nevertheless, the influence of consumption of renewable energy on unemployment has relatively acknowledged less concern and the literature in the case of Nigeria is missing. Technologies from renewable energy that consists of wind power, solar power and hydro power to mention few are considered as been labour intensive than those from non-renewable energy sources on a comparative basis and would help in increasing the global level of employment (IRENA, 2011). And the possible employment opportunities from technologies of renewable energy comprise of those in plant construction, manufacturing technologies and processing raw materials.

This investigation scrutinizes connection between renewable energy consumption and unemployment in Nigeria for the period covering 1991-2015 and the choice of this sample period was influenced by the availability of the data on all the variables and all the data for that period is sourced from World Development Indicators of World Bank. The choice of Nigeria as a case study was based on the fact the country's rate of unemployment has been high and has continued to grow over the years. Moreover, for the sample period, unemployment average was just above $4.3 \%$ and presently the rate stands above $8.0 \%$ as a percentage of total labour force modelled by international labour organization (World Bank, 2020). The high rate of unemployment has a negative effect on the general standards of living and the country's economic growth; Furthermore, there is limited evidence on the influence of consumption of renewable energy on unemployment in Nigeria and this research seeks to fill this gap. Lastly, Nigeria is among the countries with growing level of carbon emissions in the world which can be reduced by the growth in renewable energy consumption relative to renewable energy consumption.

The trends of renewable energy consumption maintained a fluctuation movement throughout the study periods and the major decline started from the beginning of the study period up to the end of the study period i.e. in 2015 . But the trend of unemployment stated by maintaining constant movement from around 1991 to 2004 and from 2005 the trend started declining until it reached 2008 and from there, the trend fluctuates again up to around 2013 and then rise upward in 2014 with little decline in 2015. In summary, the graphical trends of the relationship between the variables depicts that it is still at low level in the country for the period of 1991 to 2015.

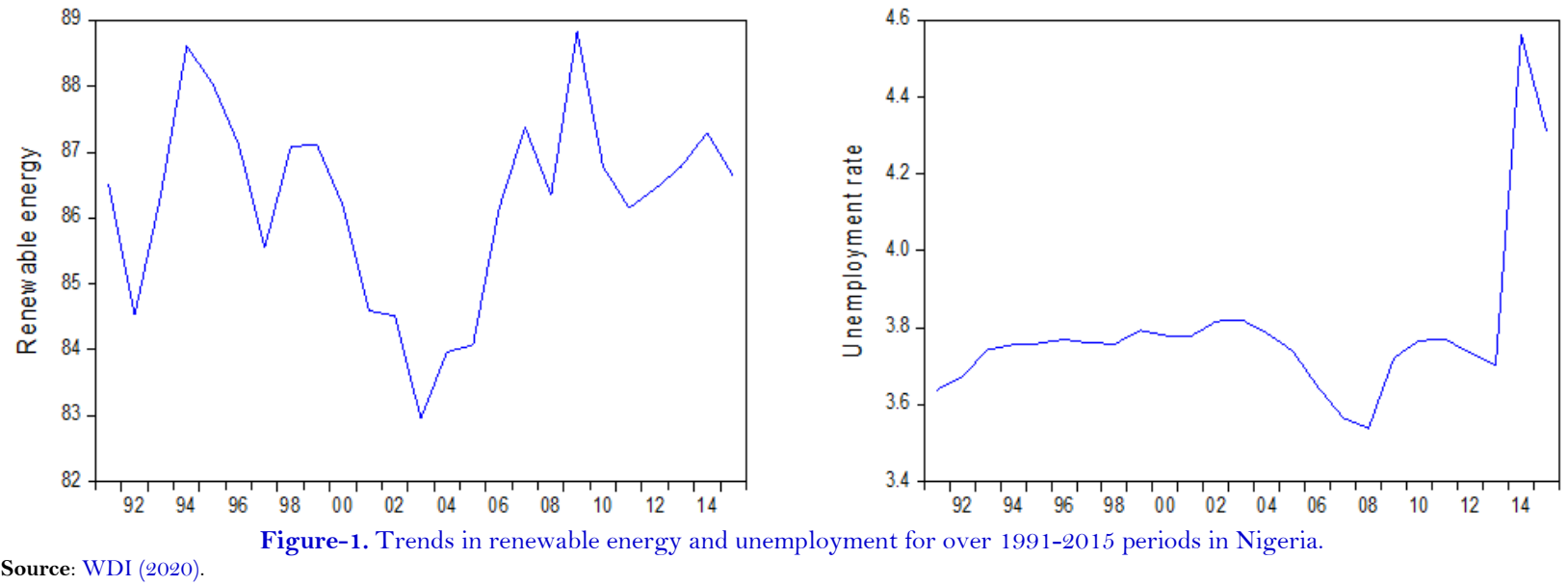


Toda and Yamamoto (1995) is engaged for estimations of long run causality between renewable energy consumption and unemployment in Nigeria. The rest of the paper is organized as follows: section two offers literature review evidence on the relationship between renewable energy and unemployment, section three deliberates on the data and methodology, section four focus on the empirical findings and discussions and the last section provide conclusion on the research.

\section{LITERATURE REVIEW}

Using the case of OECD nations and employed data on the sample period of 1980 to 2011, Salim, Hassan, and Shafiei (2014) through panel cointegration method reported that long run equilibrium connection exists between renewable energy consumption and the economic growth of these nations together with the short run causality running in a unidirectional way from economic growth to renewable energy consumption. In the case of Netherland economy, Bulavskaya and Reynès (2017) inspected the influence of consumption of renewable energy on employment generation by means of a neo-Keynesian CGEM Three-ME approach. The authors settled at the point that renewable energy conversion could generate nearly 50,000 employments by the year 2030 and consequently causing 1 percent increase in economic growth. But in the case of Egyptian economy, Khodeir (2016) recognized an opposite correlation among generation of electricity via renewable source and the rate of unemployment for the 1989-2013 periods with the help of ARDL method. The investigation is meant to notice the short and long run influence throughout the investigation period. Nevertheless, the hypothesis was found to be achieved in the long run period only. In case panel of 80 nations, Bekmez and Ağpak (2016) explored the association among non-hydro energy from renewable source and employment and resolved the presence of unidirectional causality running from employment to consumption of non-hydro energy from renewable source for the low and middle income nations but no causality was reported in the case of high income nations. The outcomes thus delivered no provision for the belief that renewable energy has a positive influence on the rate of unemployment. Apergis and Salim (2015) explored 80 nations for the period of 1990 to 2013 via unconventional unit root generation, cointegration and granger causality in a nonlinear approach using panel data. They found conflicting outcomes concerning the influence of consumption of renewable energy on unemployment. Nevertheless, total discoveries create that consumption of renewable energy has a significant positive influence on unemployment. Ahmed and Shimada (2019) in their analysis showed that there is a significant long run connection among consumption of renewable energy and supportable economic development for the developing and emerging nations that comprises of some Asian, South Asian and African nations as the research focus on the exploring the connection between consumption of renewable energy and supportable economic development. In another panel data setting covering 10 European Union (EU) member nations, Marinaş, Dinu, Socol, and Socol (2018) recognized a positive association among the consumption of renewable energy and economic growth, in Lithuania, Slovenia and Hungary. They additional originate a feedback hypothesis among renewable energy consumption and economic growth for all the member nations. Another investigation focused on the European nations was engaged by Soava, Mehedintu, Sterpu, and Raduteanu (2018) and investigation concentrates on the association among consumption of renewable energy and economic growth and their outcomes too testified a positive connection among consumption of renewable energy and economic growth with the existence of bidirectional causality running among the two series. Khobai and Le Roux (2017) scrutinized the connection among consumption of renewable energy and economic growth in the case of South Africa for 1990-2014 period. They conveyed a significant long-run connection among the series. Moreover, in the long-run, causality in a unidirectional way was reported running from renewable energy consumption to economic growth and in the short-run, from economic growth to renewable energy consumption. Using panel test for cointegration in the case of net crude oil exporting nations for the period covering 1980 to 2012, Kahia et al. (2016) showed that there exists a long-run connection among economic growth and consumption of renewable energy for the period under investigation. In the discovery of the key drivers of energy demand in Nigeria using 
ARDL and VECM techniques on the time series data for the period of 1987-2017, Musa, Maijama'a, Nafisa, and Adamu (2020) discovered that $\mathrm{CO}_{2}$ emission and economic growth have significant positive signed with energy demand while urbanization have signed negatively with energy demand in both the two periods. Additionally, longrun causality was shown in the $\mathrm{CO}_{2}$ emission and electricity consumption equations with the short-run feedback from economic growth to energy demand and urbanization to economic growth alongside single direction causality between $\mathrm{CO}_{2}$ emission to economic growth and electricity consumption to economic growth. On the influence of renewable energy consumption and economic growth in the case of Cote d'Ivoire, Kouton and Amonle (2019) employed the technique of ARDL on the time series data for over 1991 to 2015 and their outcomes revealed that there is a conflicting influence of renewable energy consumption on economic growth whereas the long-run influence is insignificant. Additionally, conversion from non-renewable energy to renewable energy consumption in the country is under the process. Using the same ARDL technique, Mohsenia and Jouzaryan (2016) scrutinized the parts played by unemployment and inflation in achieving economic growth for the 1996-2012 periods. In the long run period, the outcome showed that unemployment and inflation having significant negative effects on economic growth and this means that unemployment and inflation reduced economic growth in the long-run period in the case of Iranian economy. Maijama'a, Musa, Yakubu, and Mohammed (2019) employed the technique of DOLS on the time series data for the period of 1991 to 2017 to discover the influence of population grow th on the rate of unemployment using Nigeria as a case study. The outcome shown that rate of exchange and growth of population have positive and significant influence on the rate of unemployment while foreign direct investments, economic growth and inflation have negative influence on the rate of unemployment in the long run period. On the examination of the influence unemployment and the rate of inflation on the performance of the economy of Nigeria by means of data for the period of 1981-2014. Ademola and Badiru (2016) applied OLS technique in the analysis and the outcome of the examination shows that the rate of inflation and unemployment have significant positive influence on economic growth in the long-run. Using the same OLS technique, Imoisi, Amba, and Okon (2017) studied the influence of unemployment on economic growth of Nigeria for the sample period of 1980-2016. The outcome revealed that in the long run period, labour force, unemployment and population have significantly influenced economic growth in a positive way while the rate of minimum wage is insignificant in influencing economic growth. Ademola and Badiru (2016) shows that population growth is not the only factor accountable for the growing unemployment in the case of Nigeria since both population and unemployment grow together in their comparative study for the fact about whether unemployment is solely caused by changes in the demographic structure or other essential forces are also accountable for the social challenge using most populated nations such as China, USA and Nigeria. Using South Africa as a case study, Banda, Ngirande, and Hogwe (2016) investigated the influence of economic growth on the country's unemployment by employing data on a quarterly basis for the period of 1994-2012. The data was analyzed using VECM technique and the outcome showed that economic growth, deficit budget, real exchange rate have significant positive sign with unemployment whereas productivity of labour is related negatively with unemployment. Okwanya and Abah (2018) examined the influence that energy consumption has on reducing the level of poverty in 12 selected African nations for the sample period covering 1981-2014. Fully modified ordinary least squares and granger causality test were utilized and the outcome indicates that there is significant negative influence of energy consumption on the level of poverty and that unidirectional causality exists running from energy consumption to poverty and this implies that growing energy consumption brings about reduction in poverty.

Therefore, it can be seen that from all the available reviewed literatures provided above, similar study in the area of renewable energy consumption and unemployment in the case of Nigerian economy is lacking and that is why this study engaged T-Y procedure in filling this gap in the literature using data for the periods of 1991-2015. 


\section{DATA AND METHODOLOGY}

Data on all the variables were extracted from the world development indicators of world bank. The data measurement, definition and source are given in Table 1 and the Bar graphical illustration of the variable's trends are offered in Figure 1.

Table-1. Variables description.

\begin{tabular}{l|l|l}
\hline Series & Definition & Source \\
\hline $\mathrm{UER}_{\mathrm{t}}$ & Unemployment rate as a \% of total labour force & $\mathrm{WB}(2020)$ \\
\hline $\mathrm{RNE}_{\mathrm{t}}$ & Renewable energy consumption as \% of total final energy consumption & $\mathrm{WB}(2020)$ \\
\hline $\mathrm{INV}_{\mathrm{t}}$ & Gross fixed capital formation as a \% of GDP & $\mathrm{WB}(2020)$ \\
\hline $\mathrm{FDI}_{\mathrm{t}}$ & Foreign direct investment, net inflows \% of GDP & $\mathrm{WB}(2020)$ \\
\hline $\mathrm{CPS}_{t}$ & Credit to the private sector as a percentage of GDP & $\mathrm{WB}(2020)$ \\
\hline Note: WB stands for the World Bank; GDP is Gross Domestic Product.
\end{tabular}

\subsection{Empirical Model}

To carry out the estimation of the causal relationship among renewable energy consumption and unemployment in Nigeria for the sample period of 1991 to 2015 we have modified the model of Khobai, Kolisi, Moyo, Anyikwa, and Dingela (2019) who stated that unemployment is function of renewable energy consumption, credit to private sector, government expenditure and investment. Our modified model captured unemployment as a function of renewable energy consumption, credit to private sector, foreign direct investment and domestic investment and the functional form of the model is given in Equation 1 . $\mathrm{UER}_{\mathrm{t}}$ is the unemployment rate, $\mathrm{REC}_{\mathrm{t}}$ is the renewable energy consumption, domestic investment is given as $\mathrm{INV}_{\mathrm{t}}$, foreign direct investment is denoted as $\mathrm{FDI}_{t}$, and credit to private sector is given by $\mathrm{CPS}_{\mathrm{t}}$.

$$
U E R_{t}=f\left(R E C_{t}, I N V_{t}, F D I_{t}, C P S_{t}\right)
$$

Estimating the model in a logarithmic linear regression is better and has some advantages such obtaining and interpreting the coefficients in terms of elasticity, minimization of regression problems than the functional form model (Ahmed, Shahbaz, Qasim, \& Long, 2015; Epule, Peng, \& Lepage, 2014; Maji, 2015). Therefore, in corroboration with this statement, our log-linear model is given in Equation 2.

$$
\ln U E R_{t}=\chi_{0}+\chi_{1} \ln R E C_{t}+\chi_{2} \ln I N V_{t}+\chi_{3} \ln F D I_{t}+\chi_{4} \ln C P S_{t}+\varepsilon_{t}
$$

Here $\ln$ is the natural logarithm $\operatorname{sign} ; \chi_{1} \ldots \ldots . \chi_{4}$ are coefficients of independent series; $\ln \mathrm{UER}_{\mathrm{t}}$ represent the natural $\log$ of unemployment rate at time $t$; $\operatorname{lnREC}_{t}$ is the natural logarithm of investment; $\operatorname{lnFDI} \mathrm{I}_{\mathrm{t}}$ represent the natural $\log$ of foreign direct investment; $\operatorname{lnCPS}$ represent the natural logarithm of credit to private sector; $\varepsilon_{t}$ white noise.

\subsection{Toda and Tamamoto Long-Run Causality Technique}

For the purpose of scrutinizing the long run causality relation between renewable energy consumption and unemployment for the period under study, we have utilized the non-granger causality test by Toda and Yamamoto (1995) technique. The technique of Toda and Yamamoto causality is efficient and applicable for all the order of integration of the series and whether the series are cointegrated or non-cointegrated. This implies that whether the series are stationary at level, first difference or second difference. Rambaldi and Doran (1996); Menyah and WoldeRufael (2010); Chindo (2014) maintained that Toda and Yamamoto causality has an important feature that differentiate it from the other test for causality such as no need for pre-estimation for the purpose of determining the integrating properties of the series as well as testing for cointegration relationship and this make it convenient 
in escaping the likely predisposition that is associated these tests. The technique of Toda and Yamamoto causality is structured using augmented Vector Autoregressive (VAR) modelling method and the Wald test statistic that is connected with asymptotic chi-square $\left(\chi^{2}\right)$ values. The asymptotic chi-square $\left(\chi^{2}\right)$ values are distributed regardless of the level of stationarity and the cointegrating properties of the series. These make it fit for the VAR model on the levels of the variables and the most important part is the provision of the long run causality that is absence in another model that is based on first difference. As stated earlier, Toda Yamamoto technique involved modified Wald test for parameter restrictions of VAR (i.e. p is the system lag length). In this technique, the lag order (p) is manually increased using the maximum level of stationarity specified as " $d_{\max }$ " and it will become $\left(p+d_{\max }\right)^{\text {th }}$ by the Toda and Yamamoto technique. In our own study, we engaged Toda and Yamamoto long run non-granger causality test using VAR with 4 lags $\left(p=3\right.$ and $\left.d_{\max }=1\right)$. Hence, the matrix form of the Equation given in Equation 3 were effectively estimated and the result is reported in Table 8.

$$
\begin{gathered}
{\left[\begin{array}{l}
\ln U E R_{t} \\
\ln R E C_{t} \\
\ln I N V_{t} \\
\ln F D I_{t} \\
\ln C P S_{t}
\end{array}\right]=\eta_{0}+\eta_{1}\left[\begin{array}{l}
\ln U E R_{t-1} \\
\ln R E C_{t-1} \\
\ln I N V_{t-1} \\
\ln F D I_{t-1} \\
\ln C P S_{t-1}
\end{array}\right]+\eta_{2}\left[\begin{array}{l}
\ln U E R_{t-2} \\
\ln R E C_{t-2} \\
\ln I N V_{t-2} \\
\ln F D I_{t-2} \\
\ln C P S_{t-2}
\end{array}\right]+} \\
\eta_{3}\left[\begin{array}{l}
\ln U E R_{t-3} \\
\ln R E C_{t-3} \\
\ln I N V_{t-3} \\
\ln F D I_{t-3} \\
\ln C P S_{t-3}
\end{array}\right]+\eta_{4}\left[\begin{array}{l}
\ln U E R_{t-4} \\
\ln R E C_{t-4} \\
\ln I N V_{t-4} \\
\ln F D I_{t-4} \\
\ln C P S_{t-4}
\end{array}\right]+\left[\begin{array}{l}
\mu_{\ln U E R_{t}} \\
\mu_{\ln R E C_{t}} \\
\mu_{\ln I N V_{t}} \\
\mu_{\ln F D I_{t}} \\
\mu_{\ln C P S_{t}}
\end{array}\right]
\end{gathered}
$$

Here $\ln$ is the natural logarithm sign, $\operatorname{lnUER}_{\mathrm{t}}$ represent the natural log of unemployment rate, $\operatorname{lnREC}_{\mathrm{t}}$ is the natural logarithm of investment, $\operatorname{lnFDI}_{t}$ represent the natural $\log$ of foreign direct investment, $\operatorname{lnCPS}_{\mathrm{t}}$ represent the natural logarithm of credit to private sector, $\eta_{1} \ldots . . . \eta_{4}$ are the 4 x 4 matrices of quantities with $\eta_{0}$ identity matrix of $4 \times 1$ and $\mu_{s}$ are the disturbance terms which have zero mean and constant variance. To test the hypothesis that renewable energy consumption $\left(\operatorname{lnREC}_{t}\right)$ does not cause unemployment $\left(\operatorname{lnUER}_{\mathrm{t}}\right)$, we engaged this hypothesis:

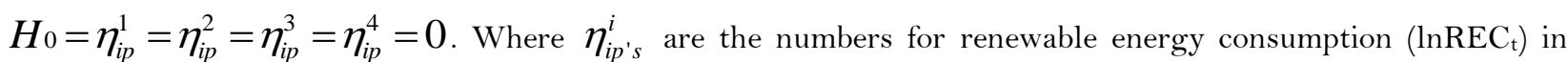
Equation 3. Likewise, to test for the reverse non causality from unemployment $\left(\ln _{\mathrm{UER}}\right)$ to renewable energy consumption $\left(\operatorname{lnREC}_{\mathrm{t}}\right)$, we used this null hypothesis: $H_{0}=\eta_{i p}^{1}=\eta_{i p}^{2}=\eta_{i p}^{3}=\eta_{i p}^{4}=0$. Where $\eta_{i p \text { 's }}^{i}$ are the numbers for unemployment in Equation 3. Again, the same process is applicable for the long run causality among the rest of the series in Equation 3.

\section{RESULTS AND DISCUSSIONS}

Figure 2 presents the graphical illustrations of renewable energy consumption, rate of unemployment, foreign direct investment, total domestic investments and credit to the private sector of the Nigerian economy for the period of 1991 to 2015. The trends of renewable energy consumption show a fluctuating movement from the first to the last period under study. The trend of unemployment rate was relatively stable from 1991 to around 2013 and the major increase was witness in the two periods of 2014 and 2015 . The trend of foreign direct investment was positive from 1991 to around 1994 and then went negative from 1995 to around 1999 and from 2000 to around 
2012 it was positive again but went back to negative form from around 2013 to the rest of the period. The trend of investment was declining from the period of 1991 up to around 2015 while the trend of credit to private sector was fluctuating from the beginning of 1991 up to around 2006 and the major increase was recorded from 2007 to around 2010 .
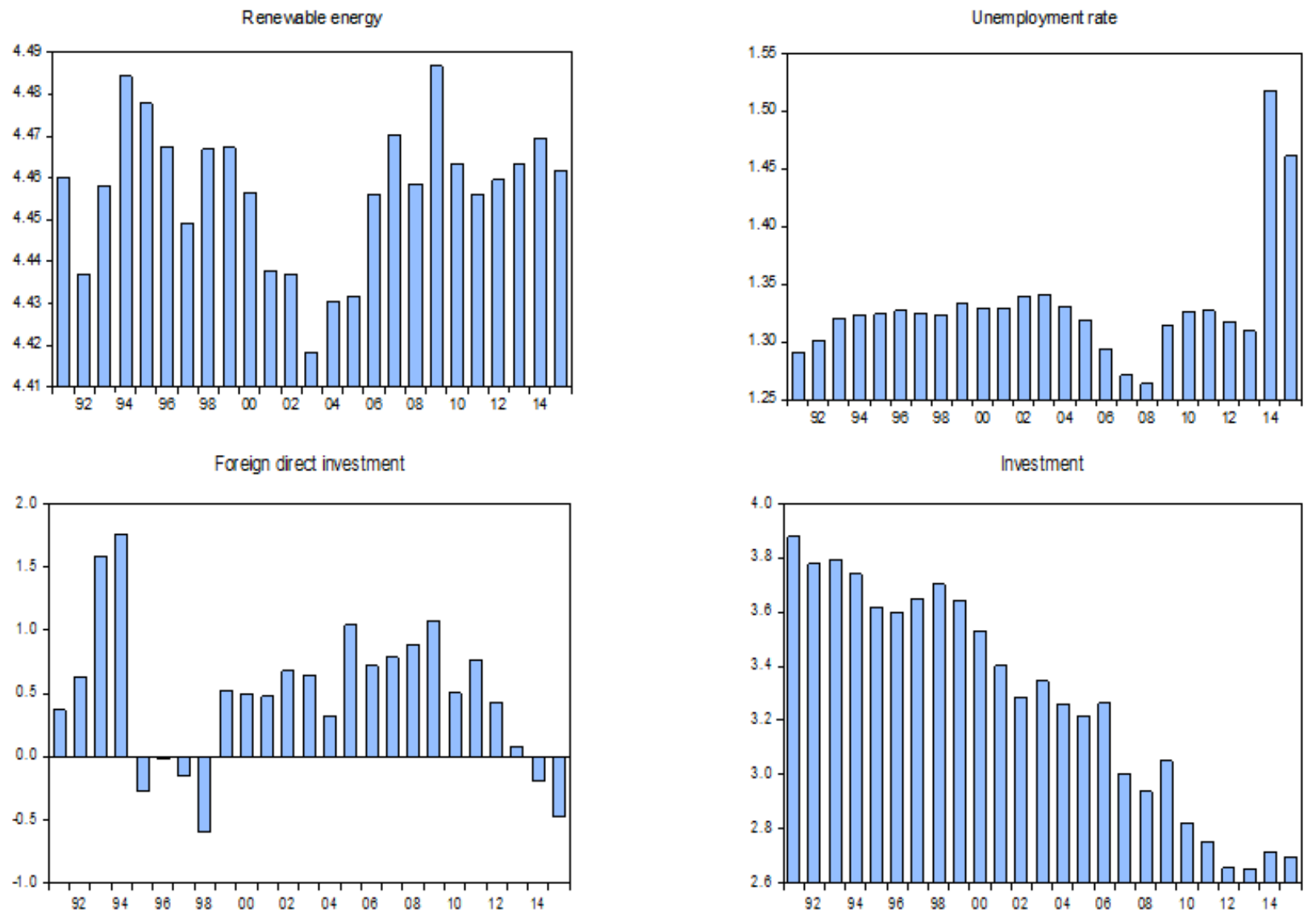

Credit to private sector

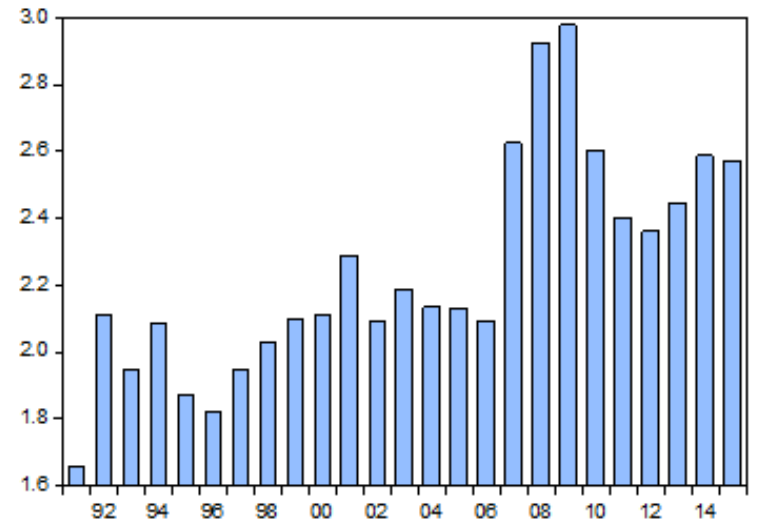

Figure-2. Trends in Renewable energy, unemployment, foreign direct investment, investments and credit to private sector for the period of 1991 to 2015.

Source: WDI (2020)

The descriptive analysis outcome in Table 2 reported the average mean, the maximum, the minimum, the skewness, the kurtosis and the Jarque-Bera test probability values for all the series. The skewness coefficients show that unemployment, foreign direct investment and credit to private sector have skewed positively while renewable energy consumption and investment have skewed negatively. The kurtosis values indicate that unemployment has 
leptokurtic distribution, renewable energy consumption, foreign direct investment and credit to private sector have platykurtic distribution while investments have mesokurtic distribution. On the basis of comparison, unemployment, renewable energy consumption, investments and credit to private sector have deviated far below their average mean values while foreign direct investment has deviated above it mean value as shown by their standard deviation values. The Jarque-Bera probability values shows that renewable energy consumption, investments, foreign direct investment and credit to private sector were normally distributed while unemployment is not normally distributed within the sample period.

Table-2. Descriptive analysis

\begin{tabular}{c|c|c|c|c|c|c|c}
\hline Series & Mean & Max. & Min. & Skew. & Kur. & SD. & P-val. \\
\hline lnUER $_{t}$ & 1.330 & 1.517 & 1.263 & 2.439 & 9.133 & 0.052 & 0.000 \\
\hline lnRNE $_{t}$ & 4.456 & 4.486 & 4.418 & -0.459 & 2.742 & 0.016 & 0.622 \\
\hline $\operatorname{lnINV}_{\mathrm{t}}$ & 3.279 & 3.879 & 2.651 & -0.218 & 1.664 & 0.409 & 0.357 \\
\hline $\operatorname{lnFDI}_{\mathrm{t}}$ & 0.482 & 1.756 & -0.600 & 0.128 & 2.911 & 0.575 & 0.962 \\
\hline $\operatorname{lnCPS}_{\mathrm{t}}$ & 2.244 & 2.976 & 1.656 & 0.572 & 2.767 & 0.330 & 0.491 \\
\hline
\end{tabular}

Table 3 report the result for the correlation analysis and the outcome indicates that all the series correlation coefficients are within the benchmark of 0.80 and this is a strong indication that our model is not suffering from multicollinearity problem (Pordan, 2013). Beside the strong indication for the non-existence of multicollinearity problem among the series, the positive correlation coefficient between renewable energy consumption and unemployment and between credit to private sector and unemployment is an indication that unemployment rate increases due to underutilization of these variables. But the existence of negative correlation between investments and unemployment and between foreign direct investment and unemployment implies that these variables have been good at reducing the rate of unemployment in the country for the period under study.

Table-3. Correlation analysis.

\begin{tabular}{c|c|c|c|c|c}
\hline Series & $\operatorname{lnUER}_{\mathrm{t}}$ & $\operatorname{lnRNE}_{\mathrm{t}}$ & $\operatorname{lnINV}_{\mathrm{t}}$ & $\operatorname{lnFDI}_{\mathbf{t}}$ & $\operatorname{lnCPS}_{\mathrm{t}}$ \\
\hline lnUER $_{\mathrm{t}}$ & 1.000 & & & & \\
\hline $\operatorname{lnRNE}_{\mathrm{t}}$ & 0.057 & 1.000 & & & \\
\hline $\operatorname{lnINV}_{\mathrm{t}}$ & -0.325 & -0.069 & 1.000 & & \\
\hline $\operatorname{lnFDI}_{\mathrm{t}}$ & -0.434 & -0.029 & 0.133 & 1.000 & \\
\hline $\operatorname{lnCPS}_{\mathrm{t}}$ & 0.149 & 0.226 & -0.776 & 0.119 & 1.000 \\
\hline
\end{tabular}

The tests employed for the presence of unit root in our analysis are DF-GLS test offered by Elliot, Rothenberg, and Stock (1996); Phillip and Perron (1988) test and Kwiatkowski, Philips, Scmidt, and Shin (1992) test. The Phillips and Perron has been criticized for having low power for a stationary series and with root near to nonstationary limit (Brooks, 2008). The DF-GLS test as maintained by the Elliot et al. (1996) has an added advantage in terms of power in the existence of unidentified mean or trend when related with PP or KPSS unit root tests. In the DF-GLS and PP tests the null hypothesis of non-stationarity is tested against the alternative hypothesis of stationarity but in the case of KPSS the reverse is the case. The outcome for the three-unit root tests are reported in Table 4 and 5 respectively.

Table 4 reports the unit root test outcomes for the constant only without trend in the series and the outcome shows that unemployment, renewable energy consumption and investments are I (0) while foreign direct investment and credit to private sector are I (1) under DF-GLS test. But all the variables were I (1) under the PP test and I (O) under the KPSS test. However, looking at the outcome in Table 5 that contains constant and trend in the series, DF-GLS test revealed that unemployment is the only I (0) whereas the rest of the series are I(1) and PP test indicates that all the series are I(1) while the KPSS test showed that all the series are $\mathrm{I}(0)$. Therefore, in 
summary there is a mixture of order of integration of the series from the three nut root tests reported and the maximum order of integration is one.

\begin{tabular}{|c|c|c|c|c|c|c|}
\hline \multirow[b]{2}{*}{ Series } & \multicolumn{3}{|c|}{ Level } & \multicolumn{3}{|c|}{ First Difference } \\
\hline & DF-GLS & $\mathbf{P P}$ & KPSS & DF-GLS & PP & KPSS \\
\hline $\operatorname{lnUER}_{\mathrm{t}}$ & $\begin{array}{c}-3.006 \\
[-2.692]]^{* * *}\end{array}$ & $\begin{array}{l}-1.749 \\
(0.394) \\
\end{array}$ & $\begin{array}{c}0.262 \\
{[0.739]^{* * * *}}\end{array}$ & $\begin{array}{c}-1.372 \\
{[-2.699]}\end{array}$ & $\begin{array}{c}-5.909 \\
(0.000)^{* * * *}\end{array}$ & $\begin{array}{c}0.203 \\
{[0.739]^{* * * *}}\end{array}$ \\
\hline$\overline{\operatorname{lnRNE}}$ & $\begin{array}{c}-2.485 \\
{[-1.955]^{* *}}\end{array}$ & $\begin{array}{l}-2.438 \\
(0.142)\end{array}$ & $\begin{array}{c}0.118 \\
{[0.739]^{\text {****** }}}\end{array}$ & $\begin{array}{c}-4.617 \\
{[-2.669]^{* * * *}}\end{array}$ & $\begin{array}{c}-5.511 \\
(0.000)^{* * * *}\end{array}$ & $\begin{array}{c}0.081 \\
{[0.739]^{* * * *}}\end{array}$ \\
\hline $\operatorname{lnINV}_{\mathrm{t}}$ & $\begin{array}{c}-0.029 \\
{[-2.664]}\end{array}$ & $\begin{array}{l}-0.416 \\
(0.891)\end{array}$ & $\begin{array}{c}0.713 \\
{[0.739]^{\text {***** }}}\end{array}$ & $\begin{array}{c}-5.416 \\
{[-2.669]^{* * * *}}\end{array}$ & $\begin{array}{c}-6.193 \\
(0.000)^{* * * *}\end{array}$ & $\begin{array}{c}0.370 \\
{[0.739]^{* * * *}}\end{array}$ \\
\hline $\operatorname{lnFDI} t$ & $\begin{array}{c}-2.624 \\
{[-1.955]^{* *}}\end{array}$ & $\begin{array}{l}-2.570 \\
(0.112)\end{array}$ & $\begin{array}{c}0.105 \\
{[0.739]^{\text {***** }}}\end{array}$ & $\begin{array}{c}-0.428 \\
{[-2.699]}\end{array}$ & $\begin{array}{c}-6.251 \\
(0.000)^{* * * *}\end{array}$ & $\begin{array}{c}0.243 \\
{[0.739]^{* * * *}}\end{array}$ \\
\hline $\operatorname{lnCPS} S_{t}$ & $\begin{array}{c}-1.517 \\
{[-2.664]}\end{array}$ & $\begin{array}{l}-2.055 \\
(0.263)\end{array}$ & $\begin{array}{c}0.602 \\
{[0.739]^{* * * *}}\end{array}$ & $\begin{array}{c}-3.781 \\
{[-2.669]^{* * * *}}\end{array}$ & $\begin{array}{c}-4.842 \\
(0.000)^{* * * *}\end{array}$ & $\begin{array}{c}0.062 \\
{[0.739]^{* * * *}}\end{array}$ \\
\hline
\end{tabular}

Table-5. Unit root tests results with intercept and trend only.

\begin{tabular}{|c|c|c|c|c|c|c|}
\hline \multirow[b]{2}{*}{ Series } & \multicolumn{3}{|c|}{ Level } & \multicolumn{3}{|c|}{ First Difference } \\
\hline & DF-GLS & $\mathbf{P P}$ & KPSS & DF-GLS & $\mathbf{P P}$ & KPSS \\
\hline $\operatorname{lnUER}_{t}$ & $\begin{array}{c}-4.042 \\
{[-3.770]^{* * * *}}\end{array}$ & $\begin{array}{l}-2.037 \\
(0.554) \\
\end{array}$ & $\begin{array}{c}0.129 \\
{[0.216]^{* * * *}}\end{array}$ & $\begin{array}{c}-1.462 \\
{[-3.770]}\end{array}$ & $\begin{array}{c}-6.092 \\
(0.000)^{* * * *}\end{array}$ & $\begin{array}{c}0.134 \\
{[0.216]^{* * * *}}\end{array}$ \\
\hline $\ln \mathrm{RNE}_{\mathrm{t}}$ & $\begin{array}{c}-2.504 \\
-3.770]\end{array}$ & $\begin{array}{l}-2.397 \\
(0.371)\end{array}$ & $\begin{array}{c}0.115 \\
{[0.216]^{* * * *}}\end{array}$ & {$\left[\begin{array}{c}-5.341 \\
-3.770]^{* * * *}\end{array}\right.$} & $\begin{array}{c}-5.350 \\
(0.000)^{* * * * *}\end{array}$ & {$\left[\begin{array}{c}0.072 \\
0.216]^{* * * *}\end{array}\right.$} \\
\hline $\ln I N V_{t}$ & $\begin{array}{c}-2.911 \\
{[-2.890]^{*}}\end{array}$ & $\begin{array}{l}-2.768 \\
(0.221)\end{array}$ & $\begin{array}{c}0.127 \\
{[0.216]^{* * * *}}\end{array}$ & $\begin{array}{c}-5.458 \\
{[-3.770]^{* * *}}\end{array}$ & $\begin{array}{c}-6.201 \\
(0.000)^{* * * *}\end{array}$ & $\begin{array}{c}0.334 \\
{[0.216]^{* * * *}}\end{array}$ \\
\hline $\operatorname{lnFDI}{ }_{t}$ & $\begin{array}{c}-2.962 \\
{[-2.890]^{*}}\end{array}$ & $\begin{array}{l}-2.600 \\
(0.283)\end{array}$ & $\begin{array}{c}0.095 \\
{[0.216]^{* * * *}}\end{array}$ & $\begin{array}{c}-1.691 \\
{[-3.770]}\end{array}$ & $\begin{array}{c}-6.141 \\
(0.000)^{* * * *}\end{array}$ & $\begin{array}{c}0.161 \\
{[0.216]^{* * * *}}\end{array}$ \\
\hline $\ln \mathrm{CPS}_{\mathrm{t}}$ & $\begin{array}{c}-3.304 \\
{[-3.190]^{* *}}\end{array}$ & $\begin{array}{l}-2.824 \\
(0.202)\end{array}$ & $\begin{array}{c}0.057 \\
{[0.216]^{* * *}}\end{array}$ & $\begin{array}{c}-4.427 \\
{[-3.770]^{* * * *}}\end{array}$ & $\begin{array}{c}-4.695 \\
(0.005)^{* * * *}\end{array}$ & $\begin{array}{c}0.047 \\
{[0.216]^{* * * * *}}\end{array}$ \\
\hline
\end{tabular}

In order to determine the best lag length for our model that is free from serial correlation and other problems, we have utilized the optimum lag length test using VAR framework and the outcome of the test is reported in Table 6. The outcome showed that four criterions suggested that lag 3 is the optimum lag for our model estimation.

Table-6. VAR optimum lag length result

\begin{tabular}{c|c|c|c|c|c|c}
\hline Lag & LogL & LR & FPE & AIC & SC & HQ \\
\hline 1 & 125.1834 & NA & $7.94 \mathrm{e}-11$ & -9.107580 & -7.867759 & -8.815516 \\
\hline 2 & 153.3220 & 30.69671 & $8.21 \mathrm{e}-11$ & -9.392912 & -6.913270 & -8.808783 \\
\hline 3 & 204.9262 & 32.83900 & $2.30 \mathrm{e}-11^{*}$ & $-11.81147^{*}$ & $-8.092008^{*}$ & $-10.93528^{*}$ \\
\hline
\end{tabular}

For the test of the long-run cointegration relationship between our variables, the Johansen and Juselius test for cointegration relationship was engaged and the outcome of the test is provided in Table 7 . The outcome revealed that there exist single cointegration relationship in both the trace and the max-eigen value statistics and the null hypothesis for no-long-run relationship among the variables is rejected and the alternative hypothesis of cointegration relationship is accepted and the series are said to be cointegrated and they moved together in the long run.

The outcome of the causal relationship between unemployment and renewable energy consumption is reported in Table 8. The outcome of the analysis indicates that renewable energy consumption and unemployment shares a significant bidirectional causality in the long-run and this implies that the country's rate of unemployment is associated with underutilization of energy from renewable source. This corroborate the empirical finding of Khodeir (2016) for Egypt and Khobai et al. (2019) for South Africa. 
Table-7. Johansen and Juselius test for cointegration result.

\begin{tabular}{c|c|c|c|c}
\hline Hypothesized No. of CE(s) & Eigenvalue & Trace Statistic & 0.05 Critical value & P-values \\
\hline \multicolumn{5}{|c|}{ Trace Test Statistic } \\
\hline $\mathrm{C} \leq 0$ & $0.935^{* * *}$ & 97.775 & 69.818 & 0.000 \\
\hline $\mathrm{C} \leq 1$ & 0.546 & 34.559 & 47.856 & 0.471 \\
\hline $\mathrm{C} \leq 2$ & 0.378 & 16.355 & 29.797 & 0.687 \\
\hline $\mathrm{C} \leq 3$ & 0.198 & 5.434 & 15.494 & 0.761 \\
\hline $\mathrm{C} \leq 4$ & 0.014 & 0.343 & 3.841 & 0.557 \\
\hline $\mathrm{C} \leq 0$ & Maximum Eigenvalue Test Statistic & 0.000 \\
\hline $\mathrm{C} \leq 1$ & $0.935^{* * *}$ & 63.216 & 33.876 & 0.478 \\
\hline $\mathrm{C} \leq 2$ & 0.546 & 18.203 & 27.584 & 0.655 \\
\hline $\mathrm{C} \leq 3$ & 0.378 & 10.921 & 21.131 & 0.730 \\
\hline $\mathrm{C} \leq 4$ & 0.198 & 5.090 & 14.264 & 0.557 \\
\hline Note: ${ }^{* * *}$ is the $1 \%$ level of significant. & 0.014 & 0.343 & 3.841 & \\
\hline
\end{tabular}

Also, significant bidirectional causality runs from foreign direct investment to unemployment in the long-run and this is an indication that foreign capital inflows helps in boosting the demand for goods and services and finally create employments. This is in line with the economic theory, the priori expectation and the empirical results of Maijama'a et al. (2019). Additionally, between investments and renewable energy consumption there exist a bidirectional causality at 1 and 10\% levels of significance and this is true because great amount of energy is highly needed to fuel the machines. This confirms the priori expectation and the Khobai et al. (2019) empirical findings for South African economy. Moreover, another bidirectional causality was found running from foreign direct investment to renewable energy consumption at $1 \%$ level of significant which is more stringent and it is in line with priori expectations that inflows of foreign capital is attached to the required amount of energy from the renewable and non-renewable sources. Furthermore, credit to private sector is also having significant bidirectional association with renewable energy consumption. Foreign direct investment has significant bidirectional causality with investment and this also confirms the priori expectations that foreign capital inflows is associated with increasing domestic investments and thereby reducing the rate of unemployment.

Table-8. Toda and Yamamoto causality test result.

\begin{tabular}{l|l|l}
\hline Null hypothesis & Chi-Square $\left(\boldsymbol{\chi}^{2}\right)$ & P-value \\
\hline Renewable energy consumption does not cause unemployment & $33.6445^{* * * *}$ & 0.000 \\
\hline Unemployment does not cause renewable energy consumption & $8.1830^{*}$ & 0.085 \\
\hline Investments does not cause unemployment & $57.5267^{* * * *}$ & 0.000 \\
\hline Unemployment does not cause Investments & 5.2442 & 0.263 \\
\hline Foreign direct investment does not cause unemployment & $8.1449^{*}$ & 0.086 \\
\hline Unemployment does not cause foreign direct investment & $597.002^{* * *}$ & 0.000 \\
\hline Credit to private sector does not cause unemployment & $37.929^{* * *}$ & 0.000 \\
\hline Unemployment does not cause Credit to private sector & 4.180 & 0.382 \\
\hline Investments does not cause Renewable energy consumption & $21.519^{* * *}$ & 0.000 \\
\hline Renewable energy consumption does not cause investments & $11.388^{* *}$ & 0.022 \\
\hline Foreign direct investment does not cause renewable energy consumption & $14.578^{* * *}$ & 0.005 \\
\hline Renewable energy consumption does not cause foreign direct investments & $565.339^{* * * *}$ & 0.000 \\
\hline Credit to private sector does not cause renewable energy consumption & $8.274^{*}$ & 0.082 \\
\hline Renewable energy consumption does not cause credit to private sector & $347.443^{* * *}$ & 0.000 \\
\hline Foreign direct investment does not cause investments & $21.748^{* * *}$ & 0.000 \\
\hline Investment does not cause foreign direct investments & $339.677^{* * *}$ & 0.000 \\
\hline Credit to private sector does not cause investments & $12.483^{* *}$ & 0.014 \\
\hline Investments does not cause credit to private sector & $347.443^{* * * *}$ & 0.000 \\
\hline Note: ${ }^{* * * * * * * *}$ stands for the 1, 5 and $10 \%$ levels of significance respectively. &
\end{tabular}

Credit to private sector and investments have a long-run bidirectional causality at $5 \%$ level of significant and it also confirms the priori expectations that credits granted to private sector of the economy will go a long way in 
boosting the level of domestic investment and as well provides employments. Apart from the bidirectional causalities among the series, unidirectional causalities also exist between investments and unemployment at $1 \%$ level of significant and this indicate that increase in domestic investment will help in generating employment opportunities and this is in line with the empirical finding of Khobai et al. (2019) for South Africa. Credit to private sector also has significant unidirectional causality with unemployment which means that credit grated to the private investors will encourage production activities and consequently generate employment opportunities. This contradict the empirical outcome of Khobai et al. (2019) for South African economy.

\subsection{Variance Decomposition and Impulse Response Function Results}

The causality direction among renewable energy consumption, unemployment, investments, foreign direct investment and credit to private sector in the case of Nigerian economy is inspected via the analysis of variance decomposition and impulse response function to capture the causality ahead of the study period. Table 9 and Figure 3 illustrates the outcomes of the analysis of variance decomposition and impulse response functions respectively, over the period of 10-years. The key motive for applying the analysis of variance decomposition and impulse response functions is because it is indifferent to the arrangement of the series in the VAR approach which make it different from the technique of orthogonalized forecast error variance (Pesaran \& Shin, 1998).

The outcomes from Table 9 indicate that about 100\%, 95.20\% and 95.03\% of unemployment is explained by own shock in the $1 \mathrm{st}, 5$ th and 10th years respectively. This implies that standard deviation shock by single digit in renewable energy consumption in the country explains unemployment by $0.14 \%$ in the 5 th year and the response reduces to $0.18 \%$ in the 10 th year. The contributions of foreign direct investment, investments and credit to private sector are $1.84 \%, 0.71 \%$ and $2.23 \%$ in the 10 th year. The reducing effect of single digit standard deviation shock in renewable energy consumption on unemployment suggests that renewable energy is not fully utilized to reduce unemployment rate in the country. The variance decomposition of renewable energy consumption revealed that unemployment contributes to $17.34 \%$ and $21.92 \%$ in the 5 th and 10 th years. This implies that underutilization of energy from the renewable sources contribute to unemployment in both the short run and the long run periods. The contributions of foreign direct investment, investments and credit to private sector were $3.89 \%, 1.72 \%$ and $0.70 \%$ in the 10 th year respectively. Around $82.58 \%$ of foreign direct investment is explained by own shocks in the 1 st year while renewable energy consumption and unemployment contributes the remaining $17.41 \%$ and $0.01 \%$ in the short run. But in the long run, unemployment, renewable energy consumption, investments and credit to private sector donates $77.54 \%, 10.75 \%, 1.66 \%$ and $4.56 \%$ respectively. This indicate that foreign capital inflows have effects on the rate of unemployment in the country. The rest of the results is offered in Table 9.

Reactions of an explain variable due to shocks from the explanatory variables in the model was captured by the impulse response function reported in Figure 3. The outcome indicates that the response of unemployment from one standard deviation shock in renewable energy consumption is positive throughout the periods. Again, the response of unemployment to single deviation standard deviation shocks in investments and credit to private sector were positive from the 1 st to 10th year. But the response of unemployment to single digit standard deviation shocks in foreign direct investment is negative throughout. The response of renewable energy consumption to single standard deviation shock in unemployment and foreign direct investment were negatively strong toward the long run. Moreover, the feedback of foreign direct investment to shock in unemployment is also negative and strong from the short run to the long run. Additionally, the feedback of investments to single shock in unemployment shows a weak positive result in the short run but became strong in the long run. Furthermore, strong negative feedback was obtained from credit to private sector due to single standard deviation shock in unemployment in both the short and the long run periods. 
Energy Economics Letters, 2020, 7(1): 46-60

Table-9. Generalized variance decomposition analysis.

\begin{tabular}{|c|c|c|c|c|c|c|}
\hline Periods & S.E. & $\operatorname{lnUER} R_{t}$ & $\ln \mathrm{RNE}_{\mathrm{t}}$ & $\operatorname{lnFDI} \mathrm{I}_{\mathrm{t}}$ & $\operatorname{lnINV_{t}}$ & $\ln \mathrm{CPS}_{\mathrm{t}}$ \\
\hline \multicolumn{7}{|c|}{ Variance decomposition of $\ln \mathrm{UER}_{\mathrm{t}}$} \\
\hline 1 & 0.051 & 100.000 & 0.000 & 0.000 & 0.000 & 0.000 \\
\hline 5 & 0.104 & 95.202 & 0.144 & 1.882 & 0.706 & 2.063 \\
\hline 9 & 0.139 & 95.060 & 0.175 & 1.846 & 0.710 & 2.206 \\
\hline 10 & 0.147 & 95.036 & 0.179 & 1.842 & 0.712 & 2.227 \\
\hline \multicolumn{7}{|c|}{ Variance decomposition of $\ln \mathrm{UER}_{\mathrm{t}}$} \\
\hline 1 & 0.015 & 0.000 & 99.999 & 0.000 & 0.000 & 0.000 \\
\hline 5 & 0.032 & 17.347 & 76.029 & 3.636 & 1.924 & 1.062 \\
\hline 9 & 0.042 & 21.526 & 72.056 & 3.901 & 1.757 & 0.757 \\
\hline 10 & 0.044 & 21.915 & 71.764 & 3.887 & 1.722 & 0.710 \\
\hline \multicolumn{7}{|c|}{ Variance decomposition of $\ln \mathrm{FDI}_{\mathrm{t}}$} \\
\hline 1 & 0.306 & 0.013 & 17.405 & 82.580 & 0.000 & 0.000 \\
\hline 5 & 1.761 & 76.138 & 10.339 & 7.102 & 1.964 & 4.454 \\
\hline 9 & 2.397 & 77.218 & 10.749 & 5.726 & 1.717 & 4.588 \\
\hline 10 & 2.535 & 77.542 & 10.752 & 5.480 & 1.665 & 4.558 \\
\hline \multicolumn{7}{|c|}{ Variance decomposition of $\ln I N V_{t}$} \\
\hline 1 & 0.092 & 14.685 & 11.315 & 43.239 & 30.760 & 0.000 \\
\hline 5 & 0.185 & 9.096 & 5.686 & 55.918 & 29.121 & 0.177 \\
\hline 9 & 0.242 & 6.509 & 4.354 & 58.990 & 29.966 & 0.179 \\
\hline 10 & 0.254 & 6.212 & 4.183 & 59.361 & 30.059 & 0.182 \\
\hline \multicolumn{7}{|c|}{ Variance decomposition of $\ln \mathrm{CPS}_{\mathrm{t}}$} \\
\hline 1 & 0.198 & 0.186 & 2.853 & 0.651 & 0.005 & 96.302 \\
\hline 5 & 0.522 & 30.412 & 2.938 & 2.489 & 0.167 & 63.992 \\
\hline 9 & 0.709 & 34.784 & 2.473 & 2.332 & 0.122 & 60.286 \\
\hline 10 & 0.750 & 35.416 & 2.411 & 2.334 & 0.113 & 59.723 \\
\hline
\end{tabular}
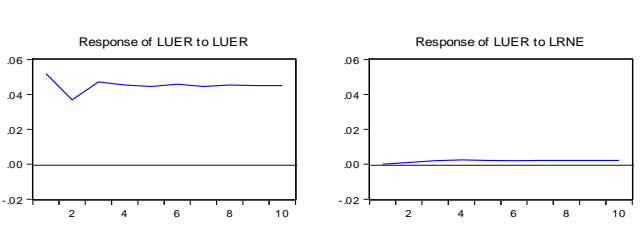

Response to Cholesky One S.D. Innovations
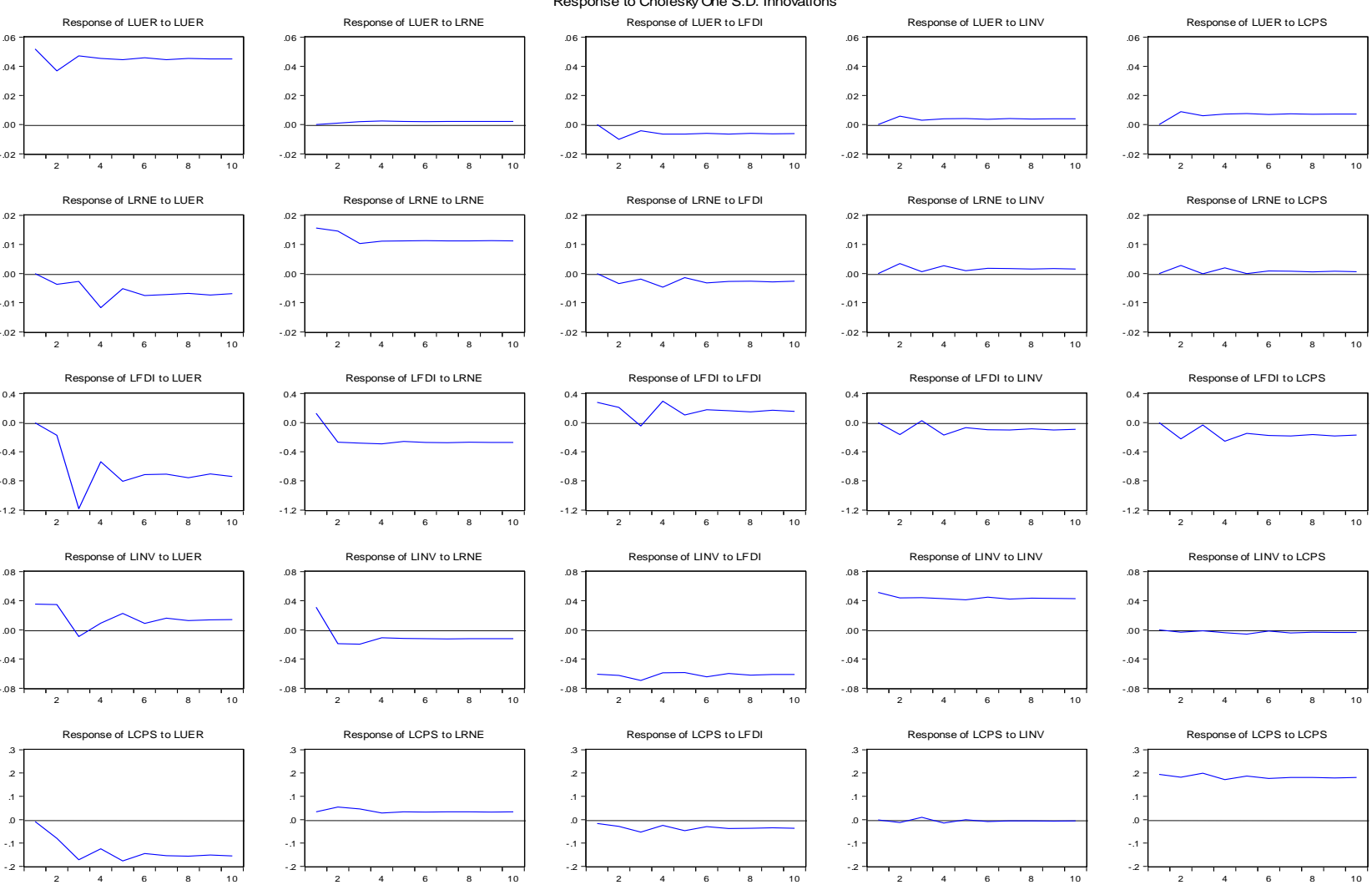

Figure-3. Impulse response functions graphs.
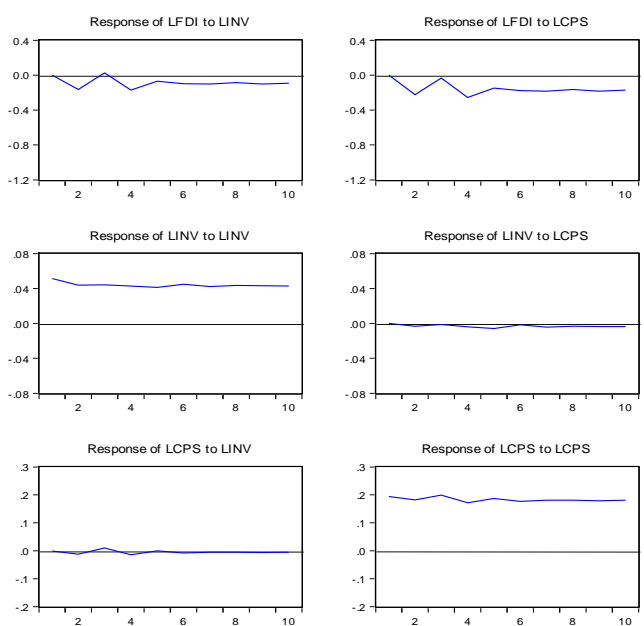

\section{CONCLUSIONS AND POLICY RECOMMENDATION}

The study examined the long run causal relationship between renewable energy consumption and unemployment in Nigeria over the period of 1991-2015 by means of Toda and Yamamoto causality technique. 
Renewable energy consumption to greater level may increase the levels of employment as technologies from renewable energy source are more of labour intensive when related with non-renewable energy ones because Nigeria is rich on renewable energy sources which include wind, solar and biofuels which could possibly help in reducing the higher rate of unemployment which stands at $27.1 \%$ as at second quarter of 2020 indicating that about 27.1 millions of Nigerians are unemployed. The outcomes from the causal analysis revealed that renewable energy consumption and unemployment are connected bidirectional in the long-run which means that renewable energy consumption in a large quantity would increase the levels of employment in the country.

Study recommends that to realize the goal of reducing the rate of unemployment in the country, government should put more efforts on increasing production and consumption of energy from renewable source as it has the tendency of decreasing the rate of unemployment in the long run and higher rate of employment is associated with increasing economic growth and improving the general welfare. Constraints to growing production and consumption of renewable energy which include higher initial price and taxes should be removed so as to boost investments in technologies that relied on renewable energy. Also, great amount of investments in infrastructure should be encouraged in the country as it will directly create employment opportunities and via future economic growth.

Funding: This study received no specific financial support.

Competing Interests: The authors declare that they have no competing interests.

Acknowledgement: All authors contributed equally to the conception and design of the study.

\section{REFERENCES}

Ademola, A., \& Badiru, A. (2016). The impact of unemployment and inflation on economic growth in Nigeria (1981-2014). International Journal of Business and Economic Sciences Applied Research, 9(1), 47-55.

Ahmad, N., \& Du, L. (2017). Effects of energy production and CO2 emissions on economic growth in Iran: ARDL approach. Energy, 123, 52 1-537. Available at: https://doi.org/10.1016/j.energy.2017.01.144.

Ahmad, N., Du, L., \& Tian, X. L. (2018). Chinese growth and dilemmas: Modelling energy consumption, $\mathrm{CO} 2$ emissions and growth in China. Quality and Quantity, 53(1), 315-338. Available at: https ://doi. org/10.1007/s1113 5-018-0755-0.

Ahmad, N., Du, L., Lu, J., Wang, J., Li, H.-Z., \& Hashmi, M. Z. (2017). Modelling the CO2 emissions and economic growth in Croatia: Is there any environmental Kuznets curve? Energy, 123, 164-172. Available at: https://doi.org/10.1016/j.energy.2016.12.106.

Ahmed, K., Shahbaz, M., Qasim, A., \& Long, W. (2015). The linkages between deforestation, energy and growth for environmental degradation in Pakistan. Ecological Indicators, 49, 95-103. Available at: https://doi.org/10.1016/j.ecolind.2014.09.040.

Ahmed, M. M., \& Shimada, K. (2019). The effect of renewable energy consumption on Ssustainable economic development: Evidence from emerging and developing economies. Energies, 12(15), 1-15.

Apergis, N., \& Danuletiu, D. C. (2014). Renewable energy and economic growth: Evidence from the sign of panel long-run causality. International Journal of Energy Economics and Policy, 4(4), 578-587.

Apergis, N., \& Salim, R. (2015). Renewable energy consumption and unemployment: Evidence from a sample of 80 countries and nonlinear estimates. Applied Economics, 47(52), 5614-5633. Available at: https://doi.org/10.1080/00036846.2015.1054071.

Banda, H., Ngirande, H., \& Hogwe, F. (2016). The impact of economic growth on unemployment in South Africa: 1994-2012. Investment Management and Financial Innovations, 13(2), 246-255. Available at: https://doi.org/10.21511/imfi.13(21).2016.11.

Bekmez, S., \& Ağpak, F. (2016). Non-Hydro renewable energy and employment: A Bootstrap panel causality analysis for countries with different income levels. Journal of Business \& Economic Policy, 3(1), 32-45.

Brooks, C. (2008). Introductory econometrics for finance (2nd ed.). USA: Cambridge. 
Bulavskaya, T., \& Reynès, F. (2017). Job creation and economic impact of renewable energy in the Netherlands. Renewable Energy, 119, 528-538. Available at: https://doi.org/10.1016/j.renene.2017.09.039.

Chindo, S. (2014). The causality between energy consumption, $\mathrm{CO} 2$ emissions and economic growth in Nigeria: An application of Toda and Yamamoto procedure. Advances in Natural Applied Sciences, 8(8), 75-81.

Elliot, G., Rothenberg, T. J., \& Stock, J. H. (1996). Efficient tests for an autoregressive unit root. Econometrica, 64(4), $813-836$.

Epule, T. E., Peng, C., \& Lepage, L. (2014). Environmental refugees in sub-Saharan Africa: A review of perspectives on the trends, causes, challenges and way forward. GeoJournal, 80(1), 79-92.

Ibrahiem, D. M. (2015). Renewable electricity consumption, foreign direct investment and economic growth in Egypt: An ARDL approach. Procedia Economics and Finance, 30, 313-323. Available at: https://doi.org/10.1016/s22 12-567 1(15)01299-x.

Imoisi, A. I., Amba, E. A., \& Okon, I. M. (2017). Unemployment rate and economic growth in Nigeria: 1981-2016. International Journal of Development and Sustainability, 6(7), 369-384.

IRENA. (2011). IRENA working paper: Renewable energy jobs: Status, prospects and policies. Retrieved from: https://www.irena.org/publications/2012/Jan/Renewable-Energy-Jobs-Status-Prospects-Policies-2012.

IRENA. (2016). Renewable energy benefits: Measuring the economics. Abu Dhabi: IRENA.

Kahia, M., Aïssa, M. S. B., \& Charfeddine, L. (2016). Impact of renewable and non-renewable energy consumption on economic growth: New evidence from the MENA net oil exporting countries (NOECs). Energy, 116, 102-115. Available at: https://doi.org/10.1016/j.energy.2016.07.126.

Khobai, H., Kolisi, N., Moyo, C., Anyikwa, I., \& Dingela, S. (2019). Renewable energy consumption and unemployment in South Africa. International Journal of Energy Economics and Policy, 10(2), 170-178.

Khobai, H., \& Le Roux, P. (2017). Does renewable energy consumption drive economic growth: Evidence from Granger causality technique. Retrieved from https://www.2017.essa.org.za/fullpaper/essa_3526.pdf. [Accessed August 21, 2020].

Khodeir, A. N. (2016). The relationship between the generation of electricity from renewable resources and unemployment: An empirical study on the Egyptian economy. Arab Economic and Business Journal, 11(1), 16-30. Available at: https://doi.org/10.1016/j.aebj.2015.10.003.

Kouton, J., \& Amonle, S. (2019). The dynamic impact of renewable energy consumption on economic growth: The case of Cote d'Ivoire. Journal of Economics and Sustainable Development, 10(18), 167-174. Available at: https://doi.org/10.7176/JESD.

Kwiatkowski, D., Philips, P. C. B., Scmidt, P., \& Shin, Y. (1992). Testing the null hypothesis of stationarity against the alternative of a unit root. Journal Econometrics, 54(1-3), 154-178. Available at: https://doi.org/10.1016/03044076(92)90104-Y.

Larcher, D., \& Tarascon, J.-M. (2015). Towards greener and more sustainable batteries for electrical energy storage. Nature Chemistry, 7(1), 19-29. Available at: https://doi.org/10.1038/nchem.2085.

Maijama'a, R., Musa, K. S., Yakubu, M., \& Mohammed, N. (2019). Impact of population growth on unemployment in Nigeria: Dynamic OLS approach. Journal of Economics and Sustainable Development, 10(22), 79-89. Available at: https:// doi.org/10.7176/JESD/10-22-09.

Maji, I. K. (2015). The link between trade openness and deforestation for environmental quality in Nigeria. Geo Journal, 82(1), 131-138.

Marinaş, M.-C., Dinu, M., Socol, A.-G., \& Socol, C. (2018). Renewable energy consumption and economic growth. Causality relationship in Central and Eastern European countries. PloS one, 13(10), e0202951. Available at: https://doi.org/10.1371/journal.pone.0202951.

Menyah, K., \& Wolde-Rufael, Y. (2010). Energy consumption, pollutant emissions and economic growth in South Africa. Energy Economics, 32(6), 1374-1382. Available at: https://doi.org/10.1016/j.eneco.2010.08.002.

Mohsenia, M., \& Jouzaryan, F. (2016). Examining the effects of inflation and unemployment on economic growth in Iran (19962012). Procedia Economics and Finance, 36, 381-389. Available at: https://doi.org/10.1016/s2212-5671(16)30050-8. 
Musa, K. S., Maijama’a, R., Nafisa, M., \& Adamu, Y. (2020). Assessing the key drivers of energy demand in Nigeria: Application of ARDL Approach. Global Scientific Journals, 8(6), 19-40.

Okwanya, I., \& Abah, P. O. (2018). Impact of energy consumption on poverty reduction in Africa. CBN Journal of Applied Statistics, 9(1), 105-139.

Pesaran, H. H., \& Shin, Y. (1998). Generalized impulse response analysis in linear multivariate models. Economics Letters, 58(1), 17-29. Available at: https://doi.org/10.1016/s0165-1765(97)00214-0.

Phillip, P. C. B., \& Perron, P. (1988). Testing for a unit root in time series regression. Biometrika, 75(2), 335-346. Available at: https://doi.org/10.1093/biomet/75.2.335.

Pordan, I. (2013). The effects of whether on stock returns: A comparison between emerging and developed markets. Originalausgabe. Hamburg, Germany: Anchor Academic Publishing.

Rambaldi, A. N., \& Doran, T. E. (1996). Testing for granger non-causality in a cointegrated system made easy. Working Papers in Econometrics and Applied Statistics, 88, Department of Econometrics, University of New England.

Salim, R. A., Hassan, K., \& Shafiei, S. (2014). Renewable and non-renewable energy consumption and economic activities: Further evidence from OECD countries. Energy Economics, 44, 350-360. Available at: https://doi.org/10.1016/j.eneco.2014.05.001.

Sebri, M., \& Ben-Salha, O. (2014). On the causal dynamics between economic growth, renewable energy consumption, CO2 emissions and trade openness: Fresh evidence from BRICS countries. Renewable and Sustainable Energy Reviews, 39, 1423. Available at: https://doi.org/10.1016/j.rser.2014.07.033.

Soava, G., Mehedintu, A., Sterpu, M., \& Raduteanu, M. (2018). Impact of renewable energy consumption on economic growth: Evidence from European Union countries. Technological and Economic Development of Economy, 24(3), 914-932. Available at: https://doi.org/10.3846/tede.2018.1426.

Toda, H. Y., \& Yamamoto, T. (1995). Statistical inference in vector auto regressions with possibly integrated processes. Journal of Econometrics, 66(1-2), 225-250. Available at: https://doi.org/10.1016/0304-4076(94)01616-8.

WDI. (2020). World Bank's world development indicators. Retrieved from https://data.worldbank.org/indicator.

World Bank. (2020). World Bank’s world development indicators. Retrieved from: https://data.worldbank.org/indicator.

Views and opinions expressed in this article are the views and opinions of the author(s), Energy Economics Letters shall not be responsible or answerable for any loss, damage or liability etc. caused in relation to/arising out of the use of the content. 